Bajopas Volume 2 Number 2 December, 2009

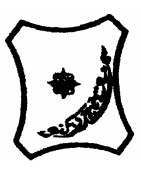

Bayero Journal of Pure and Applied Sciences, 2(2): 49 - 52

Received: March, 2009

Accepted: August, 2009

\title{
FUTURE PROSPECTS FOR ETHANOL FUEL USE - A REVIEW
}

*Garba Ahmed, Sulaiman Abubakar and Nasir Ma'aruf Ahmed

Department of General Studies, Jigawa State College of Agriculture, P.M.B. 013 Hadejia

*Correspondence author

\begin{abstract}
Countries inspired by a desire to reduce greenhouse gas emissions in order to meet their Kyoto Protocol targets, have turned to ethanol fuels as a cheap and proven alternative to reduce vehicular emissions. Political instability in the Middle East has further motivated countries to develop their own fuel supply to ensure the security of supply and promote internal economic growth. The use of fuel ethanol has attracted considerable negative press and public comments in the early part of 2000s. Because of the importance of ethanol fuel as alternative to petrol, this review presents discussions outlining the various benefits and costs of using fuel ethanol with the objective of highlighting the future prospects of its use to reduce greenhouse gas emissions, provide cheap energy source for vehicles and also provide income to farmers producing bio-ethanol.
\end{abstract}

Key words; ethanol fuel, future prospects, conflicting needs

\section{INTRODUCTION}

Ethanol is the most common biofuel worldwide. It is an alcohol fuel produced by fermentation of sugars derived from wheat, corn, sugar beet and sugar cane. The production methods used are enzymatic digestion (to release sugars from stored starches e.g. from wheat and corn), fermentation of the sugars, distillation, dehydration and drying. Ethanol can be used in petrol engines as a replacement for gasoline, and can also mix with gasoline to any percentage such as $10 \%$ ( containing $90 \%$ petrol).

In the past few years, the prospects for ethanol fuel use have grown around the world. Once confined to a few specialized countries, ethanol production and consumption have begun to spread to all corners of the globe. Currently produced from the starch or sugar in a wide variety of crops, there is some debate about the viability of bio-ethanol as a replacement for fossil fuels. Public concerns include the large amount of arable land required for crops, and the energy/pollution balance of the ethanol production cycle. While cellulosic ethanol research and development promises to allay those concerns, most analysts agree that large-scale production is not expected in the near future.

Brazil, the pioneer of the modern ethanol fuel industry in the 1970s, still remains both the dominant producer and consumer of ethanol fuels, though in recent years, the industry has grown dramatically in the United States, Europe, Africa, and Asia. In 2002, the global ethanol consumption reached 38.3 billion litres and is projected to exceed 41.3 billion litres by 2005(Gobi International, 2003) .The current trend in fuel ethanol production and consumption has reached over 50 billion litres and has become slightly steady as a recent sharp drop in petrol price(Gobi International, 2008). This volume is still tremendously small $(1 \%)$ in terms of transport fuels however, as worldwide oil consumption in 2002 exceeded 4,000 billion litres (AP Energy Business Publication, 2003).
Ethanol Production Policies

There have been a number of different policy strategies undertaken by governments wishing to develop a domestic ethanol fuels programme. Ethanol fuels are most commonly introduced into the fuel market through blends with gasoline. Many countries have mandated blends of a certain percentage in domestic gasoline supplies. In Brazil, with the most highly developed ethanol fuel pro-gramme, gasoline supplies contain up to $25 \%$ ethanol. In 2003 , both India and China unveiled regional pilot programmes with the eventual goal of introducing $10 \%$ blends throughout their domestic gasoline supplies. While these policies don't necessarily mandate the use of ethanol.

\section{Ethanol Use Policies}

Ethanol and its substituent ethyl-tertiary-butyl ether (ETBE) are the most viable replacements for methyltertiary-butyl-ether, (MTBE), an octane enhancer in gasoline. Seventeen states in the United States have banned or severely limited the use MTBE and the federal government is currently considering a nationwide ban, in the hopes of introducing renewable fuels to the country's transport sector. Thus a ban on MTBE gives ethanol almost complete control over the oxygenate market. Other countries have pursued a renewable fuels standard (RFS) that specifies a volume of ethanol to be used in transportation fuels at some point in the future. The United States Congress is currently debating a RFS that would increase domestic ethanol use from 9.5 billion litres in 2002 to 19 billion by 2012. In 2001, the European Union established goals for the percentage of member states' fuels to be bio-based by 2020, aiming for $20 \%$ biofuels by that time (Yacobucci and Womach 2002). Still other countries have pursued tax breaks and subsidies for ethanol fuel production and use. 
In 2001, the European Union issued a directive to allow member states to adjust their excise tax structures in order to favour the use of fuels ethanol. In 2002, India revised its Sugar Development Fund Act to allow the government to give concessionary loans to sugar mills trying to upgrade their ethanol production capabilities. Subsidies are in place to reduce the cost of ethanol fuels to consumers in the United States, Australia, and many others.

\section{Ethanol Technologies and Trade}

The future of ethanol fuels appears to be bright, as countries around the world have begun to pursue aggressive ethanol strategies in recent years. One of the issues surrounding the future of ethanol comes from the prospect of international trade in ethanol. While one of the major justifications for ethanol fuels seems to be a desire to maintain a secure domestic supply, importation of ethanol could provide the fuel to many countries at a greatly reduced cost and on the other hand it ensure poor food crops yields as farmers turned to produce fuel crops. However, most countries have high importation tariffs on ethanol to make imported fuel uncompetitive with the domestic supply. In the United States, there is 54 cents per gallon tariff that protects ethanol suppliers in the Midwest states benefit from cheaper ethanol supplies that could be imported from Brazil or elsewhere in South America (MacDonald, 2003).

One of the beauties of loosening these trade restrictions on ethanol is that this will allow developed countries, who are unable to produce ethanol as cheaply as many equatorial developing countries to obtain the fuels at a reduced cost, while providing for economic development to countries that desperately seek it. Furthermore, the spread of ethanol trade allows the transfer of technologies from experienced ethanol producers to fledgling programs in other countries. For example, a Brazilian ethanol company announced in 2002 that it would install an ethanol refinery in Portugal to help, "back the EU's policy of promoting clean fuels" (Renewable Energy Report, 2003).

Developments in ethanol fuel technologies are also likely to reduce costs and make ethanol an increasingly attractive option to consumers and governments. In 2003, Volkswagen released its first flex-fuel vehicle, capable of running on fuel with any blend of ethanol and gasoline. Research into production of ethanol from cellulose-based feedstocks could allow producers to extract ethanol from corn stalks, sugarcane leaves, and other forms of organic waste. These technologies are likely to reduce feedstock costs, which could make ethanol fuels considerably more affordable, especially in developed countries. Dedini SA, a Brazilian ethanol-engineering firm, announced in June 2003 that it had developed such technologies to extract ethanol from sugarcane leaves in addition to cane juice. It estimates that this technology could double the amount of ethanol produced per hectare of sugarcane (Knights, 2003).

\section{Benefits to be Gained}

Whilst the recent controversy on the use of high ethanol content fuel dominated the daily press, the main arguments that have long been advanced in favour of fuel ethanol include environmental benefits, the development of regional industries, and supplementation of the national fuel supply. Ethanol production from agricultural crops including wheat and sugarcane is also regarded as 'renewable' and sustainable.

Another reason why ethanol fuels are so attractive is that they represent an environment-friendly technology that is available today. While ethanolfuelled automobiles are probably not likely to be the permanent solution to environmental concerns in automotive fuels, in the very least, they provide a temporary solution while research into fuel cells and other advanced technologies are under development. By investing in such practical technologies today, governments around the world enjoy significant environmental progress as well as domestic economic development, and realize two goals that often appear at odds with one another. As countries around the world begin to take note of the benefits provided by ethanol fuels and develop their own programmes, it is important to consider what the future might hold for ethanol fuels and how emerging technologies and policies can help guide this development in a desirable direction.

There are still many issues to be addressed in considering the future of ethanol fuels. Many critics have charged that the energy balance of ethanol fuels is flawed, arguing that the energy inputs exceed the energy content of the final product. However, a study released by the United States Department of Agriculture in July of 2002 refutes these claims and finds that ethanol has an output: input energy ratio of 1.34:1(Shapouri et al,.2002).Furthermore, another study found that the energy balance of gasoline is actually negative, giving ethanol a 1.42:1 output energy ratio compared to gasoline (Alternative fuels data center, 2003).

Perhaps even more important than the energy balance from an environmentalist perspective is the amount of carbon released in the production of the fuel as compared to its final energy content. If agricultural processes and transportation of ethanol release large enough quantities of carbon dioxide, running a vehicle on ethanol could potentially result in higher carbon emissions than a clean diesel or gasoline engine. Thus, some have argued that ethanol fuels should be evaluated based on their carbon dioxide balance, indicative of the production process. For example, due to the photosynthetic efficiency advantage of sugarcane over corn and a large ethanol transportation infrastructure already established, ethanol in Brazil has a much lower carbon dioxide emissions: final energy ratio, than ethanol produced in the United States. At present, there is no distinction made between the two types of ethanol fuels, despite the fact that the Brazilian ethanol reduces considerably more carbon dioxide emissions. Recognition of this dissimilarity is essential to making ethanol fuels sustainable and maximizing the environmental benefits of its use (Lindqvist, 2003). 


\section{Conflicting Needs}

It is important to consider the carbon dioxide released during ethanol production, and the effects of drastically increasing agricultural production in order to meet an increased demand for the fuel( increased agriculture necessitates more land use change, more pesticides, and more fertilizer) all of which bring a host of different environmental concerns. Scientists debate the extent to which agricultural capacity can be expanded to meet a global demand for ethanol, especially as the rapidly growing population in the developing world struggles to feed itself. While all of these externalities can be addressed to yield an ethanol fuel that is better for the environment than our conventional fossil fuel-based consumption, it is important to consider them and not blindly accept the environmental benefits of ethanol fuels just because they are cleaner at the tailpipe.

Most mainstream environmental groups support fuels ethanol as a significant step toward slowing or stopping global climate change. However, fuel ethanol production can threaten the environment if it is not done sustainably.

Fuel ethanol produces greenhouse gas emissions during their manufacture. The sources of these emissions are: fertilizers and agricultural processing, transportation of the biomass, processing of the fuels, and transport and delivery of biofuels to the consumer. Some fuel ethanol production processes produce far fewer emissions than others; for example sugar cane cultivation requires fewer fertilizer inputs than corn cultivation, therefore sugar cane bioethanol reduces greenhouse gas emissions more effectively than corn derived bioethanol. However, given the appropriate agricultural techniques and processing strategies, biofuels can provide emissions savings of at least $50 \%$ when compared to fossil fuels such as diesel and petroleum (Smith, 1993).

According to many analysts, the major obstacle to ethanol fuels becoming more widespread is simply a question of cost. However, there is great potential that these costs can be considerably reduced as more widespread ethanol use generates increased attention towards the science and economics behind ethanol fuels production. As ethanol production is presently dependent on agricultural feedstocks, which comprise anywhere from $30-60 \%$ of the total cost of production, minimizing feedstock costs are central to making ethanol fuels more affordable to consumers.

Much of this focus has been devoted to converting the entire feedstock plant into useful end products, allowing ethanol costs to decrease as manufacturing becomes more profitable. In southern Africa, whose primary ethanol feedstock is sugarcane, there have been efforts to restrict the practice of burning sugarcane residues in the fields after harvesting. Instead these residues, as well as sugarcane bagasse (a fibrous waste-product of sugarcane extraction), can be used for electricity cogeneration, allowing the plant to cover its own energy needs and even export electricity to the surrounding communities (Johnson, 2000). Many alcohol plants in Brazil already sell excess electricity to local utilities. Maintaining the capacity to convert these waste products into electricity or ethanol could also give alcohol producers additional stability by insulating them from price volatility in either the ethanol or electricity markets.

In addition to converting these feedstock waste products into electricity, research into production of ethanol from cellulose-based feedstocks (woody materials, stalks, and leaves) could allow these agricultural residues to be converted into more ethanol. Additional research into ethanol extraction from cellulose feedstocks promises to reduce ethanol costs by running production on the relatively cheap waste products of the agriculture and timber industries. Additionally, the use of cellulose-based feedstocks appeases concerns that a reliance on ethanol fuels could divert food from the rapidly growing world population by providing farmers with a secondary flow of revenue; the technology could instead make food more affordable to the world's poor since crop displacement has been minimal, and has little effect on food prices, ethanol advocates says.

\section{RECOMMENDATIONS}

1) The governments should develop ethanol trading programmes that will enhance the affordability of ethanol fuels in comparison to gasoline and diesel.

2) The governments should use tradable permits as a means of encouraging car manufacturers to sell alternative fuelled vehicles.

3) The governments should introduce a wellreasoned policies and technological advancement in ethanol fuels that could guide a smooth transition away from fossil fuels in the transportation sector.

4) The use of bio-ethanol as alternative to conventional petroleum products require a substantial shift in public attitudes probably towards an acceptance of paying a premium for motor biofuels, and any new engine technology. Such changes would require change of the fuel market; governments should provide subsidies and tax incentives and possibly a pollution or carbon tax.

5) Governments should encourage and support research into ethanol extraction from cellulose feed stocks as it promises to reduce ethanol costs by running production on a relatively cheap waste products of the agriculture and timber industries.

6) The use of cellulose- based feed stocks appeases concerns that a reliance on ethanol fuels could divert food from the rapidly growing world population. The governments should provide farmers with a secondary flow of revenue; the technology could instead make food more affordable to the world's poor. 
7) A combination of well-reasoned government policies and technological advancements in ethanol fuels could guide a smooth transition away from fossil fuels to ethanol fuel use in the transportation sector. An environmental

\section{REFERENCES}

Alternative Fuels Data Center (2003): Alternative Fuels Comparison Chart. May, 2003.

AP Energy Business Publications (2003): "World Oil Supply More Diverse with Non-OPEC Production Increasing." July 2003.pp.13-18

Gobi International (2003): Ethanol - The International Market 2003. London, UK: 2003.p.21

Gobi International (2008): Ethanol - The International Market 2008. London, UK: 2008.p.78

Johnson, F. (2000): "Sugarcane Resources in Southern Africa." Tiempo: Global Warming and the Third World. March 2000.p.207

Knights, P. (2003): "New Flex-Fuel Engines Transform Consumer Options in Brazil" F.O. Lichts: World Ethanol and Biofuels Report, July 23, 2003.pp.87-95

Lindqvist, R. (2003): Marketing Director, Salixsphere. Personal interview, August 18, 2003. externalities should continue be incorporated into policy consideration and the fledgling industry emerges, ethanol fuels are likely to become and increasing attractive fuel alternative in the foreseeable future.

MacDonald, T. (2003): California Energy Commission. Email interview, August 14, 2003

Renewable Energy Report, (2003):"Ethanol Ideas Exported From Brazil." Issue 52, June 2003.pp.121-159

Shapouri, H., James D., and Michael W. (2002): "The Energy Balance of Corn Ethanol: An Update." United States Department of Agriculture, July, 2002.p.55, 63

Smith, R. (1993): "Ethanol, a clear future". Coach and buses week. Conference on Ethanol-powered buses programm, Stockholm, $10^{\text {th }}$ July, 1993.

Yacobucci, B.D, Womach, J. (2002):'Fuel Ethanol: Background and Policy Issues', Congressional Research Service, the Library of Congress, 2 July 2002. 